\title{
MUS CAROLINENSIS.
}

\author{
Carolina Mouse.
}

M. Dilute plumbeus, auribus longis et pilosis, cauda corpore longiore.

\section{CHARACTERS.}

Tail longer than the body; ears long and hairy. Color light plumbeous.

\section{SYNONYMES.}

Mus Carolinensis.-Aud. and Bach, Jour. Acad. Nat. Sci., Phila., vol. viii., part ii., p. 306.

“ " Le Conte, Proc. Acad. Nat. Sci., Phila., p. —, 1853.

\section{DESCRIPTION.}

In size this species is smaller than the house mouse. The upper foreteeth are slightly grooved. The head is short, the forehead arched, and the nose rather blunt. Eyes small, but prominent; whiskers longer than the head. The ears are rather long, and have a very conspicuous incurvation of their anterior margins, which are fringed with hairs; they are thickly clothed on both surfaces with very short hairs. The legs and feet are small and slender, hairy to the nails. The thumb is almost entirely composed of a short convex nail. The tail is long, clothed with short hairs, rounded in the living animal, but square when in a dried state. The fur, which is of moderate length, is thin, soft, and silky.

\section{COLOUR.}

The incisors are light yellow, tipped with black; eyes black; point of the nose, lips, chin, fore-feet, and nails, white. Whiskers dark brown. There is a narrow fawn-coloured ring around the eyes. Ears, legs, and tail light ashy brown. The fur on the back and sides is from the roots of an uniform light plumbeous colour; the under surface is scarcely a shade lighter. 
DIMENSIONS.

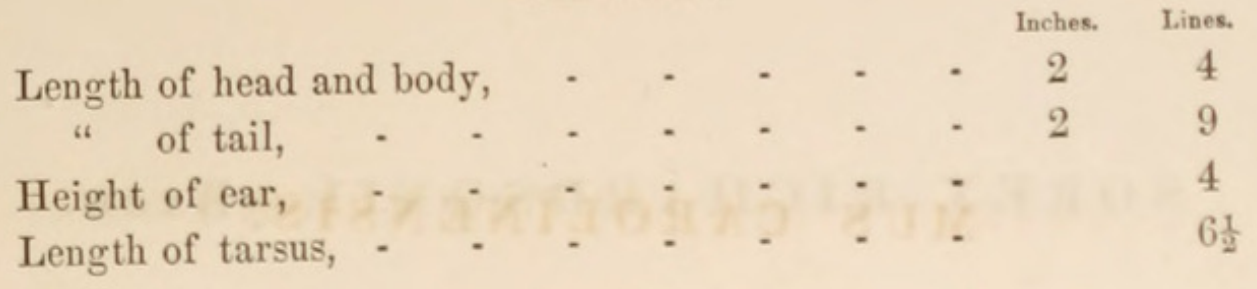

\section{GENERAL REMARKS.}

This species exists very sparingly in the maritime districts of South Carolina, and is usually found in low grounds partially inundated. It readily takes to the water, and swims with great facility. 


\section{$2 \mathrm{BHL}$ Biodiversity Heritage Library}

Audubon, John James and Bachman, John. 1854. "Mus carolinensis, Carolina Mouse." The quadrupeds of North America 3, 332-333.

https://doi.org/10.5962/p.322488.

View This Item Online: https://www.biodiversitylibrary.org/item/108515

DOI: https://doi.org/10.5962/p.322488

Permalink: https://www.biodiversitylibrary.org/partpdf/322488

\section{Holding Institution}

Duke University Libraries (archive.org)

\section{Sponsored by}

Duke University Libraries

\section{Copyright \& Reuse}

Copyright Status: Not provided. Contact Holding Institution to verify copyright status.

This document was created from content at the Biodiversity Heritage Library, the world's largest open access digital library for biodiversity literature and archives. Visit BHL at https://www.biodiversitylibrary.org. 